Review

http://dx.doi.org/10.17784/mtprehabjournal.2014.12.200

\title{
Effects of stretching exercises for posture correction: systematic review.
}

\section{Efeitos de exercícios de alongamento para correção postural: revisão sistemática.}

José Nunes Da Silva Filho(1), Jonas Lírio Gurgel(2), Flávia Porto(3).

Instituto de Educação Física e Desportos, Universidade do Estado do Rio de Janeiro (UERJ), Rio de Janeiro (RJ), Brazil.

\begin{abstract}
Introduction: Nowadays, postural problems are widely discussed concerns because they involve quality of life and interfere with the functional aspects of individuals. Thus, muscle stretching exercise is suggested as useful in treating postural deviations. Objective: To investigate the effect of muscle stretching on body posture and analyze aspects of prescription and evaluation methods in order to relate the proposed training and results. Method: This systematic review was previously registered and accepted in International Registry Of Systematic Reviews (PROSPERO, id: CRD42013005280), and described according to the recommendations of the PRISMA. The search data began with the choice of key terms and their synonyms, according to the Descritores em Saúde (DeCS) and MeSH. After, seeking material was performed on the major databases of scientific information (SciELO; PEDro, PubMed and Google Scholar). The studies that met the eligibility criteria underwent an evaluation as to their methodological quality based on the Brazilian - Portuguese version of the PEDro scale. Results: It was found seven clinical trials, methodologically scored, following Pedro scale, which showed little evidence about the topic, which contain significant limitations and/or low methodological quality. Conclusion: There are few evidence on the effectiveness of the intervention with exercise stretching in correcting postural deviations, making it difficult to reach consensus or conclusions.
\end{abstract}

Keywords: Stretching Static-Passive; Posture; Spinal Diseases.

\section{Resumo}

Introdução: Problemas posturais são preocupações muito discutidas, na atualidade, por envolverem qualidade de vida e interferir nos aspectos funcionais dos indivíduos. Para isso, o exercício físico de alongamento muscular vem sendo sugerido como eficaz no tratamento de desvios posturais. Objetivo: Verificar o efeito do alongamento muscular sobre a postura corporal e analisar aspectos da prescrição e os métodos de avaliação com o intuito de relacionar o treinamento proposto e os resultados obtidos. Método: Esta revisão sistemática foi, previamente, registrada e aceita no registro internacional de revisões sistemáticas (PROSPERO, ID=CRD42013005280), e descrita segundo as recomendações do PRISMA. A busca de dados iniciou-se com a escolha dos termos-chaves e seus sinônimos, segundo os Descritores de Saúde (DeCS) e o MeSH. Após, foi realizada busca de materiais nas principais bases de dados de informação científica (SciELO; PEDro, PUBMED e Google Acadêmico). Os estudos que atenderam os critérios de elegibilidade passaram por uma avaliação quanto às suas qualidades metodológicas baseados na versão Português-Brasileiro da escala PEDro. Resultados: Foram encontrados sete ensaios clínicos, pontuados, metodologicamente, seguindo a escala Pedro, que apresentaram pouca evidência sobre o tema abordado por conter consideráveis limitações e/ou baixa qualidade metodológica. Conclusão: Existem poucas evidências sobre a eficácia da intervenção com o exercício físico de alongamento na correção de desvios posturais, dificultando estabelecer consenso ou conclusões.

Palavras-Chaves: Alongamento estático-passivo; Postura; Doenças da Coluna Vertebral.

Submission date 19 May 2014; Acceptance date 25 August 2014; Publication date 2 September 2014

1,3. Laboratory of Physical and Health Promotion, Institute of Sports and Physical Education, State University of Activity Rio de Janeiro (UERJ), Rio de Janeiro (RJ), Brazil.

2. Professor of post graduated program in Science of Health Care and of post graduated program in Cardiovascular Sciences, Fluminense Federal University (UFF), Niterói (RJ), Brazil.

Flávia Porto - Laboratório de Atividade Física e Promoção da Saúde, IEFD, UERJ - Rua São Francisco Xavier, n 524 - sala 8.133 - bloco F. Bairro Maracanã - Zip Code: 20550-013, Rio de Janeiro - RJ. Brazil. - Phone/ fax: (55xx21) 2334-0775 - E-mail: flaviaporto_@ terra.com.br/flavia_porto@msn.com 


\section{INTRODUCTION}

The muscle stretching exercises have been recommended as a complementary form of physical activity programs aimed at high yield performance, treatment of musculoskeletal injuries and health promotion. ${ }^{(1,2)}$ In recent years, studies have pointed to the beneficial effect of muscle stretching in injury prevention, ${ }^{(3,4)}$ in reduction of delayed-onset muscle soreness, ${ }^{(5,6)}$ attenuation of postural changes in the spine, $(7,8)$ or other motor skills. (9) However, there are still doubts about the appropriate prescribing of these exercises and the real benefits on bipedalism body posture.

Whereas the standing posture is linked directly to several structural changes related to upright bipedal which happen with the development from birth to adulthood, and specifically in the musculoskeletal system ${ }^{(10)}$ as also having the flexibility of these factors, ${ }^{(11)}$ seems to be consistent think, hardly there will be an individual with the 'ideal' posture biomechanically. That is, one where the physiological curvature of the spine are adhered in a better load distribution and alignment member $^{(12)}$ without increasing or decreasing angles existing in the spine ${ }^{(13)}$ or increasing muscle overload, ${ }^{(14)}$ It also may generate pain. ${ }^{(14,15)}$

Factors such as lifestyle and prolonged maintenance of posture determined, ${ }^{(16)}$ anthropometric characteristics, as, large abdominal perimetry, ${ }^{(10)}$ sports practi$\mathrm{ce}^{(17)}$ and advanced age ${ }^{(10,18)}$ may generate unfavorable biomechanical compensation to health of the individual. (19) This reinforces the fact that changes in postural curvatures interfere, not only in aesthetics but can compromise the quality of life of the person, mainly by causing pain and, therefore, interfere with the performance of activities of daily living. $(15,20,21)$ The pain related to postural deviations of the column seems to be related, possibly to muscle imbalance in the trunk region, including activation level and muscle fatigue. ${ }^{(22,23)}$

Regarding specifically body alignment, flexibility training programs seem to result positively in postural realignment, especially in the vertebral column and pelvic sagittal position, with visible effects immediately following the achievement of stretching exercises. ${ }^{(24)}$ In a chronic way, stretching can also contribute significantly. ${ }^{(25)}$ However, there are studies that examined the acute effect (after exercise) and chronic liabilities and static stretching in the posture of adults and the results were inconclusive. ${ }^{(26)}$

Besides there are few systematic reviews on the specific topic, it is possible that the lack of consensual about the real benefits of stretching exercises on the standing posture, ${ }^{(7,10)}$ can be explained by the lack of specific exercises for the public it proposes. ${ }^{(27,28)}$ In addition, there may be inadequate manipulation of the variables of the proposed training, inappropriate choice of method of postural assessment ${ }^{(28,29)}$ or even lack of in- formation in studies that enables replicability of physical training proposed.

The aim of this systematic review was to evaluate the effect of muscle stretching on body posture and analyze aspects of training prescription due to verified consistency between the proposed training, evaluation methods and results. The hypothesis is that there is a crafted lack of standardization in postural assessment and prescription of flexibility training.

\section{METHODS}

This systematic review ${ }^{(30)}$ was previously registered on the basis of PROSPERO (International Prospective Register of Systematic Reviews), ${ }^{(31)}$ under no ID = CRD42013005280. The research followed the recommendations of the PRISMA Statement. (32) The selection of papers was conducted in the databases of SciELO, PEDro, PubMed and Google Scholar data, and the selection and choice of studies made by Physical Education teachers.

\section{Search}

Initially, there was a selection of key terms, through the Descritores em Ciências da Saúde ${ }^{(33)}$ - a structured and trilingual vocabulary created by the Biblioteca Regional de Medicina (BIREME) - and MeSH (Medical Subject Headings), which is the thesaurus used for indexing articles for PubMed.

The terms used for the search, in Portuguese, were: Muscle Stretching and its synonyms (Exercício de Estiramento Muscular and Exercício de Alongamento Muscular), and Postura. The terms were separated by "AND" and the synonyms separated by "OR": the Boolean operators "AND" and "OR" were used. In English, the search was conducted as follows: ("Exercises, Muscle Stretching" or "Muscle Stretching Exercise" or "Dynamic Stretching" or "Stretching, Dynamic" or "Isometric Stretching" or "Stretching, Isometric" or "Active Stretching "or" Stretching, Active "or" Static Stretching-Active "or" Active Stretching Static "or" Stretching, Static-Active "or" Static Stretching "or" Stretching, Static "or" Passive Stretching "or" Stretching, Passive "or "Relaxed Stretching" or "Stretching, Relaxed" or "Static-Passive Stretching" or "Static Passive Stretching" or "Stretching, Static-Passive" or "Ballistic Stretching or Stretching, Ballistic" or "Proprioceptive Neuromuscular Facilitation (PNF) Stretching") AND ("posture").

\section{Inclusion criteria}

Experimental studies using the stretching exercise in isolation as an independent variable in acute and/or chronic intervention checking the effects on the dependent variable (postural deviations) in almost static position were selected, not including studies that found a dynamic posture, or performed concurrently training of 
other physical valences. If the study did not meet these criteria, would be excluded from the search.

\section{Eligibility Criteria}

Studies have remained the inclusion filter, passed through a selection, by reading technique "Without going into detail" ("Skimming"), suggested by Lakatos and Marconi(34) wherein a read is done title followed by read the summary and parts of the text, trying to find the methodology and the essence of the work. If still remained doubt as to the selection of the article, performed the technique of reading Scanning ("Scanning"), which, according to Kleiman, ${ }^{(35)}$ is a brief reading of the entire work in order to select only the papers that meet the selection criteria.

\section{Article analyze}

The selected studies underwent an evaluation of their methodological qualities based on the Brazilian-Portuguese version of the PEDro scale, ${ }^{(36)}$ which is based on Delphi list.(37) The PEDro scale consists of 11 items that make up a total of 10 points, if all items are reached. At the end of all eligibility criteria, seven studies were included, 2 of Master's Theses and 05 scientific articles. Figure 1 shows the process of selection of works for this search:

\section{RESULTS}

Seven experimental studies were found, two Masters dissertations and five articles. All with the goal of checking the answers of the stretching exercise on body posture in adults. In Table 1, methodological details of these studies are presented, describing them as the

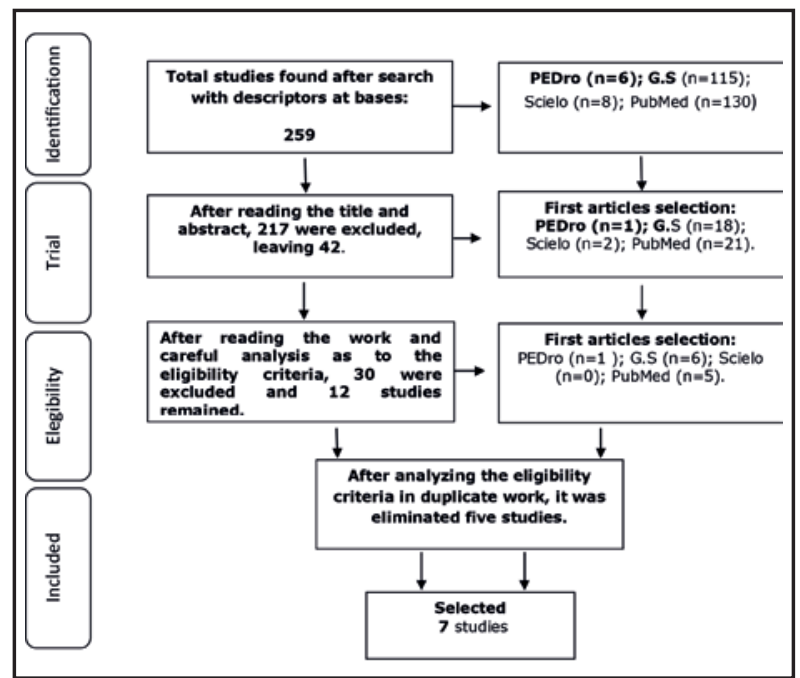

Figure 1. Flowchart of selection of articles. Subtitle: G.A = Google Scholar

Table 1. Main features and results of the studies included in the systematic review.

\begin{tabular}{|c|c|c|c|c|c|c|}
\hline TS & Author & PEDro & Subjects & $\begin{array}{c}\text { Age } \\
\text { (years) }\end{array}$ & Intervention & Outcomes \\
\hline CA & $\begin{array}{l}\text { Marques et } \\
\quad \text { al. }(42)\end{array}$ & 4 & $20 M$ & 23 a 61 & $\begin{array}{l}\text { 3-11 sessions of stretching short- } \\
\text { ened muscle chains, during } 02 \\
\text { weeks. }\end{array}$ & $\begin{array}{l}\text { At the end, all patients had a more } \\
\text { upright posture, leading to the } \\
\text { belief that there was a significant } \\
\text { stretching of the posterior chain. }\end{array}$ \\
\hline CA & Li et al. ${ }^{(44)}$ & 6 & $\begin{array}{l}39 \text { (W e M), } \\
\text { em EG (19) } \\
\text { e CG (20) }\end{array}$ & $29.3 \pm 3.5$ & $\begin{array}{l}10 \text { times a day. for } 3 \text { weeks. Static } \\
\text { stretching of the posterior chain, } 1 \\
\text { series of } 15 \text { s tension and } 15 \text { s rest. }\end{array}$ & $\begin{array}{l}\text { There were no significant changes } \\
\text { in lumbar-pelvic posture pre and } \\
\text { post-tests to stretching exercises } \\
\text { for the posterior chain. }\end{array}$ \\
\hline MT & Do Rosário(45) & 5 & $\begin{array}{l}30 W-\text { Lo- } \\
\text { cated in } 3 G\end{array}$ & $21.7 \pm 1.7$ & $\begin{array}{l}\text { G1 and G2. } 30 \mathrm{~min} \text { sessions, } 2 x / \\
\text { week for } 3 \text { weeks and } 48 \mathrm{~h} \text { interval, } \\
\text { G1: } 2 \text { global elongation of } 15 \mathrm{~min} \\
\text { each, G2: } 14 \text { Stretching exercises } \\
\text { 1min segment liabilities. G3 GC. }\end{array}$ & $\begin{array}{l}\text { G1 was superior in reducing devia- } \\
\text { tions from the anterior iliac spine } \\
\text { and posterior-. There was no } \\
\text { difference between groups in the } \\
\text { scapular alignment variable. }\end{array}$ \\
\hline MT & Camargo $^{(26)}$ & 3 & $8 W$ e $8 M$ & $23.13 \pm 2.1$ & $\begin{array}{l}1 \text { session active stretch: standing } \\
\text { and hip flexion to } 90^{\circ} \text {, for } 12 \mathrm{~min} \text {. } \\
2-2 \mathrm{~min} \text { intervals each being al- } \\
\text { lowed, when the subject thought } \\
\text { necessary. }\end{array}$ & $\begin{array}{l}\text { There were no significant changes } \\
\text { in spinal curvatures, the angle of } \\
\text { the lumbar curvature, lateral trunk } \\
\text { tilt and sacral slope. }\end{array}$ \\
\hline CA & $\begin{array}{l}\text { Hashimoto et } \\
\qquad \text { al. }(43)\end{array}$ & 3 & 11 subjects & $37.1 \pm 14.5$ & $\begin{array}{l}20 \text { sessions of } 1 \text { hour each with } \\
\text { active stretching, } 02 x / \text { week for } \\
3-4 \text { months. }\end{array}$ & $\begin{array}{l}\text { Significant changes reducing the } \\
\text { unevenness of the shoulders, } \\
\text { misalignment of the hip, lateral } \\
\text { inclination of the trunk and head } \\
\text { misalignment (frontal plane). }\end{array}$ \\
\hline CA & $\begin{array}{l}\text { Lopes-Minarro } \\
\text { et al.(24) }\end{array}$ & 3 & 55 subjects & $29.2 \pm 7.41$ & $\begin{array}{l}1 \text { session } 8 \mathrm{~min} \text { static stretching, } \\
\text { being } 4 \text { years of hip flexion, with } \\
\text { three series of } 20 \mathrm{~s} \text { and } 30 \text { s volt- } \\
\text { age range. }\end{array}$ & $\begin{array}{l}\text { Static stretching of the hamstring } \\
\text { muscles was associated with im- } \\
\text { mediate changes in the curvatures } \\
\text { of the spine and pelvic position in } \\
\text { the sagittal plane. }\end{array}$ \\
\hline CA & Muyor et al.(46) & 6 & $\begin{array}{l}\text { 58W. CG } \\
\text { (31) EG } \\
\text { (33) }\end{array}$ & $44.2 \pm 8.8$ & $\begin{array}{l}12 \text { weeks, } 3 x / \text { week: stretching } \\
\text { hamstrings, } 20 \text { s voltage. }\end{array}$ & $\begin{array}{l}\text { The stretching caused increased } \\
\text { extensibility of the hamstring } \\
\text { muscles, generating a line thoracic } \\
\text { curve. }\end{array}$ \\
\hline
\end{tabular}

Subtitle: TS = Type of study; MT = Master Theses; CA= Cientific Article; W = Woman; M = Man; G= Group; CG = Control group; EG = Experimental group; $\mathrm{s}=$ seconds; $\mathrm{min}=$ minuts; $\mathrm{GPR}=$ Global Postural Reeducation. 
characteristics of individuals assessed, type of intervention and main outcomes found.

It might also be noted, in seven studies, the presence of 05 different instruments to assess posture, with Computerized Photogrammetry and Spinal Mouse the only appear in more than one study (Table 2).

\section{DISCUSSION}

\section{Classification of articles}

The methodology of the selected studies was verified by the methodological PEDro scale, ${ }^{(36)}$ which has been widely shown in the areas of rehabilitation, ${ }^{(38-40)}$ and serves to assess the methodological quality of experimental studies. When the score was equal to or greater than 5 , considered a high quality study, ${ }^{(41)}$ is less than this, it was considered of low methodological quality.

An important factor found in this study refers to methodological limitations in the studies presented. According to the adopted criteria, most (57.1\%) of the analyzed studies $(24,26,42,43)$ had low methodological quality ${ }^{(41)}$ and less than half $(42.9 \%)$, studies ${ }^{(44-46)}$ showed high methodological quality.

Among the limitations found in the studies, it was noted that only three studies(44-46) used a control group, none of them made any kind of blinding, and only one study, ${ }^{(24)}$ performed the sample size calculation and statistical power. In this regard, it is emphasized that these strategies would enable explain why the non-significant results of interventions - due to inefficiency to the intervention or the sample size. ${ }^{(39)}$ These data end up making interpretation of results, by interfering with the ability to trial of the intervention.

\section{Postural assessment methods}

After observation of the instruments used in pos- tural assessments of the mentioned clinical trials (Table 2 ), it was noted that photogrammetry was the most used among studies, ${ }^{(26,43,45)}$ then decreasingly, the Spinal Mouse system ${ }^{(24,46)}$ Metrecom $^{(44)}$ and Schober and Stibor. ${ }^{(42)}$

Even the photogrammetry being more present in the studies, it was noted the presence of other 4 instruments, assuming that researchers have been using the instruments according to their expertise or even by infrastructure availability. Another assumption regarding the plurality in the use of these instruments, it is speculated to be related to how complex it is to detect and/or faithfully transcribe the deviations of various segments of the body posture.

The lack of consensus on methods, instruments or even the reliability of these significantly threaten the interpretation and conclusion of the effectiveness of the proposed interventions to alleviate postural deviations. $(28,29)$ The fact that diversity of instruments used to assess body posture, considering the limited number of studies, it becomes a negative factor for the understanding and comparison of results. Also, sometimes the study reported the instrument used, however, kept dark and/or incomprehensible details of their use. . $^{(2-44)}$

In the case of computerized photogrammetry, this is a widely used technique which is the combination of digital photographs analyzed in software that enable the measurement of angles and horizontal and vertical distances. ${ }^{(47)}$ In Brazil, the technique has been used in clinical trials ${ }^{(26,43,45)}$ and in cross-sectional studies ${ }^{(48-51)}$ have recently considered the most used technique in Brazilian studies. ${ }^{(52)}$

The popularization of computerized photogrammetry can be explained by the advantages it offers to allow an assessment that requires the evaluated only a few moments. ${ }^{(53)}$ This quickly can contribute to improved re-

Table 2. Characteristic of postural assessment methods used in the studies.

\begin{tabular}{|c|c|c|c|c|}
\hline$n^{\circ}$ & Study & IAP & Descrição dos métodos & PCA \\
\hline 1 & Marques et al. ${ }^{(42)}$ & Schober and Stibor & $\begin{array}{l}\text { Checks with tape, the distance between the spinous processes of } \\
\text { the vertebral column between two measurement points previously } \\
\text { marked by an assessor. }{ }^{(63)}\end{array}$ & Trunk \\
\hline 2 & Li et al.(44) & Metrecom Software & $\begin{array}{l}\text { Electronic scanner-dimensional probe that after scanning the images, } \\
\text { vectors and angles through analyzes of Cartesian coordinates. }{ }^{(44)}\end{array}$ & Trunk \\
\hline 3 & Do Rosário(45) & $\begin{array}{l}\text { Computerized photo- } \\
\text { grammetry }\end{array}$ & $\begin{array}{l}\text { Combination of digital photo software that allows to measure hori- } \\
\text { zontal and vertical angles and measures (47). }\end{array}$ & Body \\
\hline 4 & Camargo $^{(26)}$ & $\begin{array}{l}\text { X-ray; e } \\
\text { computerized pho- } \\
\text { togrammetry }\end{array}$ & $\begin{array}{l}\text { a) X-ray: the gold standard for evaluation of postural deviations of the } \\
\text { spine by means of radiography offering a view of all your vertebrae } \\
\text { and their curvatures. }{ }^{(64)} \text { Frontal and sagittal plane. } \\
\text { b) See study }\left(n^{\circ} 3\right) \text {. }\end{array}$ & Spine \\
\hline 5 & Hashimoto et al. ${ }^{(43)}$ & $\begin{array}{l}\text { computerized photo- } \\
\text { grammetry }\end{array}$ & See study n.3 & Body \\
\hline 6 & Lopes-Minarro et al. (24) & $\begin{array}{l}\text { SpinalMouse }{ }^{\circledR} \\
\text { Sistem }\end{array}$ & $\begin{array}{l}\text { Device for computer assisted measurements spanning angles and } \\
\text { angles of the vertebral column movement, evaluated in the sagittal } \\
\text { plane.(65) }\end{array}$ & Spine \\
\hline 7 & Muyor et al. ${ }^{(46)}$ & $\begin{array}{l}\text { SpinalMouse }{ }^{\circledR} \\
\text { Sistem }\end{array}$ & See study $n^{\circ} 6$ & Spine \\
\hline
\end{tabular}


liability of the method, which does not happen in predominantly subjective evaluations, which usually take longer and increase the risk of bias ${ }^{(54)}$ Other advantages are: Validity, reliability measures ${ }^{(53,55-57)}$ and - why not? - Low cost, which makes it quite affordable method and worked in large and small research groups.

Aspects of interventions and acute effect of stretching posture

From the analyzed studies, 02 verified the acute effect of stretching exercise on spinal curvatures and showed conflicting results. In the first study, Camargo et al. (26), had a sample of 16 men and women, with mean age of 23.13( \pm 2.1$)$ years, not reporting whether or not the volunteers practiced physical activities before study. The second study, Lopez-Miñarro et al.(24) evaluated 55 police officers with mean age 29.24( \pm 7.41$)$ years who did not exercise, only physical leisure activities.

In the first study, ${ }^{(26)}$ volunteers were exposed to one session of global active stretching of the posterior muscle chain, one 12 min session being held in a static position allowing 01-02 min intervals when evaluated showed physical fatigue. The pre and post-intervention ratings showed no significant changes in spinal curvatures. The second study ${ }^{(24)}$ experienced one session hamstring stretch with four exercises with three sets lasting 20 to 30 s rest period between sets. In this case, the authors found immediate changes in spinal curvatures and pelvic sagittal position.

When compared, the studies showed no consensus on the effectiveness of the intervention, and in only one significant changes. When evaluated in terms of methodology, ${ }^{(37)}$ both showed score 3, which, according to Sherrington et al.., ${ }^{(41)}$ is considered of low methodological quality. Still limitation, the studies showed no control group and this threatens the external validity of these studies. ${ }^{(30)}$ According to Jadad et al. ${ }^{(58)}$ it is critical to reducing the risk of bias, can provide secure evidence to serve as proposals new interventions.

Therefore, it is evident the need for new studies on the acute effects of stretching exercise for posture correction, more appropriate methodologies so that they have better understanding about the subject.

\section{Aspects of interventions and chronic effects of stretching posture}

On the chronic effects of stretching on body posture, met four studies, and all of them showed significant responses about the effectiveness of the intervention, with the exception of the study by Li et al., ${ }^{(44)}$ that after the training program, not observed significant changes in the posture of volunteers.

As for the other works, showed significant results in correcting postural deviations. ${ }^{(42,43,45,46)}$ In the study by Marques, ${ }^{(42)}$ the author submitted the 20 volunteers between 3-11 sessions of stretching for more than two weeks and noted that all the participants at the end of the study, showed a more upright posture. Rosario(45) allocated 30 women in 03 equal groups, G1: 2 were globally stretching exercises with 15 min each and G2, passive stretching exercises targeting with 1 min each exercise performed. In both groups, each session lasted 30 min, held 2 times weekly for 3 weeks; the third group was the control. The G1 showed significant improvements in postural alignment when compared to other groups.

Hashimoto et al.(43) evaluated twenty subjects who underwent 20 sessions of active stretching, 1 hour, 2 times weekly for 3-4 months. At the end of the study, subjects showed significant changes in posture to reduce the unevenness of the shoulders and hips, head misalignment with the 7th cervical vertebra in left lateral view, and lateral bending of the trunk and left $\mathrm{Q}$ angle in anterior view. Muyor et al.(46) had conducted on 27 women with intervention stretching exercises of the series 20 s duration, at a frequency of 3 times per week for 12 weeks. When compared with the 31 women in the control group, the experimental group had a more rectified thoracic curve.

Of the 05 studies reviewed, 04 found the chronic effects of stretching exercise on posture and detect efficacy in reducing postural deviations. Further, it was observed that in the study there were no significant changes, ${ }^{(44)}$ a prescription of the exercise atypical recommended in the literature was performed. That's because the volunteers performed the exercises daily, with 15 $\mathrm{s}$ of tension for $15 \mathrm{~s}$ of rest between them series. And when confronted with indications in the literature, the suggestion that the stretching exercises provide long-term physiological changes are needed 2-4 times per week on alternate days. Moreover, the elongation must be at least 20 to $30 \mathrm{~s}$ of stress, ${ }^{(59,60)}$ especially when the goal is to maintain body posture according to the guidelines of the American College of Sport Medicine. ${ }^{(61)}$

Since the other studies, although they have shown significant improvements in body posture after the intervention, when verified methodologies, 50\% had high methodological quality ${ }^{(45,46)}$ and the other, low quality, due to lack of detail in the description of the method. $(42,43)$ Its was also found the average PEDro score of the studies using the technique previously used in a systematic review of Coury, Moreira and Dias, ${ }^{(40)}$ adding the total score and dividing by the number of studies found. From this analysis was obtained an average PEDro score of 4.2 points, assuming a low average be in order when sorted individually, studies should present a PEDro score $\geq 5$ points to consider studies of high methodological quality. ${ }^{(41)}$

The limitations presented in the 04 studies, 02 of them ${ }^{(42,43)}$ did not use a control group, which is described by Jadad et al., ${ }^{(58)}$ as key in reducing bias and methodo- 
logical provision of safe evidence for reproducibility studies. Also, was not found in any description of them as the use of techniques of blinding, sample size calculation and statistical power. Beyond these methodological limitations, it was noticed little ${ }^{(46)}$ or no description ${ }^{(42,43)}$ of the variables used in the training exercise stretching programs proposed intervention, such as volume intensity, recovery etc. All these limiting aspects found in studies end up generating a substantial reduction in methodological quality, ${ }^{(37)}$ providing no evidence safer as the actual effectiveness of the intervention ${ }^{(58)}$ and decreasing the external validity of these studies. ${ }^{(30)}$

However, a systematic review to obtain reliable conclusions will literally depend on the quality of studies which it observed. ${ }^{(62)}$ Thus, it is evident that althou$\mathrm{gh}$ there is a tendency on the positive effects of exercise in chronic stretching alignment of body posture, $(42,43,45,46)$ no need to carry out new studies with better detailed methodological descriptions, and presenting in more detail the exercise program used in interventions.

\section{CONCLUSION}

This review showed that for the acute effects of stretching exercise aimed at correcting postural deviations, there is still no consensus in the literature that supports its effectiveness. As for the chronic effects, although noticed a slight trend as to its benefits in postural correction, literature, yet also presents little evidence to support this assumption.

The studies also showed little methodological description, noting that there is still need for further clinical trials with high methodological quality and more detailed descriptions of the proposed exercise stretching progra$\mathrm{ms}$, contributing to secure evidence for clinical practice.

\section{REFERENCES}

1. American College of Sports Medicine. American College of Sports Medicine Position Stand. The recommended quantity and quality of exercise for developing and maintaining cardiorespiratory and muscular fitness, and flexibility in healthy adults. Med Sci Sports Exerc. 1998; 30(6):975-91.

2. Garber CE, Blissmer B, Deschenes MR, Franklin BA, Lamonte MJ, Lee IM, et al. American College of Sports Medicine position stand. Quantity and quality of exercise for developing and maintaining cardiorespiratory, musculoskeletal, and neuromotor fitness in apparently healthy adults: guidance for prescribing exercise. Med Sci Sports Exerc. 2011; 43(7):1334-59.

3. Pope RP, Herbert RD, Kirwan JD, Graham BJ. A randomized trial of preexercise stretching for prevention of lowerlimb injury. Med Sci Sports Exerc. 2000; 32(2):271-7.

4. Herbert RD, Gabriel M. Effects of stretching before and after exercising on muscle soreness and risk of injury: systematic review. BMJ: British Medical Journal. 2002; 325(7362):468.

5. Smith LL, Brunetz MH, Chenier TC, McCammon MR, Houmard JA, Franklin ME, et al. The effects of static and ballistic stretching on delayed onset muscle soreness and creatine kinase. Res Q Exerc Sport. 1993; 64(1):103-7.

6. Herbert RD, de Noronha M, Kamper SJ. Stretching to prevent or reduce muscle soreness after exercise. Cochrane Database Syst Rev. 2007; (7):CD004577.

7. Kado DM. The rehabilitation of hyperkyphotic posture in the elderly. European journal of physical and rehabilitation medicine. 2009;45(4):583-93.

8. Burke TN, Franca FJ, Ferreira de Meneses SR, Cardoso VI, Marques AP. Postural control in elderly persons with osteoporosis: Efficacy of an intervention program to improve balance and muscle strength: a randomized controlled trial. American journal of physical medicine \& rehabilitation / Association of Academic Physiatrists. 2010; 89(7):549-56.

9. Rubini EC, Costa AL, Gomes PS. The effects of stretching on strength performance. Sports medicine. 2007; 37(3):213-24.

10. Porto F, Gurgel JL, Russomano T, Farinatti PdTV. Shadow Moire technique to measure deformity of the trunk surface in the elderly: a population-based study In: Bessette A, Rousseau, Coralie $M_{,}$, editors. Scoliosis: Causes, Symptoms and Treatment. New York: Nova Biomedical; 2012. p. 73-90.

11. Hinman M. Comparison of thoracic kyphosis and postural stiffness in younger and older women. The Spine Journal. $2004 ; 4(4): 413-7$.

12. Kendall F, McCreary E, Provance P. Músculos: provas e funções - com postura e dor. 4 ed. São Paulo: Manole; 1995

13. Briggs AM, van Dieen JH, Wrigley TV, Greig AM, Phillips B, Lo SK, et al. Thoracic kyphosis affects spinal loads and trunk muscle force. Phys Ther. 2007; 87(5):595-607.

14. Kawano MM, Souza RBd, Oliveira3 BIRd, Menacho MO, Cardoso APRG, Nakamura FY, et al. Comparação da fadiga eletromiográfica dos músculos paraespinhais e da cinemática angular da coluna entre indivíduos com e sem dor lombar. Rev Bras Med Esporte. 2008; 14(3):209-14. 
15. Takahashi T, Ishida K, Hirose D, Nagano Y, Okumiya K, Nishinaga M, et al. Trunk deformity is associated with a reduction in outdoor activities of daily living and life satisfaction in community-dwelling older people. Osteoporos Int. 2005; 16:273-9.

16. Vieira A, de Souza JL. Verticalidade é sinônimo de boa postura? Movimento (ESEF/UFRGS). 2007; 5(10):I-VIII.

17. Uetake U, Ohtsuki F, Tanaka H, Shindo M. The vertebral curvature of sportsmen. J Sports Sci. 1998; 16:621-8.

18. Gasparotto J, Morais Junior A. Desvios posturais em escolares de 06 e 07 anos de idade. Revista Brasileira de Prescrição e Fisiologia do Exercício. 2010; 4(23):433-9.

19. SIQUEIRA G, da Silva GAP. Alterações posturais da coluna e instabilidade lombar no indivíduo obeso: uma revisão de literatura. Fisioterapia em Movimento (PUCPR Impresso). 2011; 24:557-66.

20. Aebi M. The adult scoliosis. European spine journal : official publication of the European Spine Society, the European Spinal Deformity Society, and the European Section of the Cervical Spine Research Society. 2005; 14:92548.

21. Dolphens M, Cagnie B, Coorevits P, Vanderstraeten G, Cardon G, D'Hooge R, et al. Sagittal standing posture and its association with spinal pain: a school-based epidemiological study of 1196 Flemish adolescents before age at peak height velocity. Spine. 2011; 37(19):1657-66.

22. Yahia A, Jribi S, Ghroubi S, Elleuch M, Baklouti S, Habib Elleuch M. Evaluation of the posture and muscular strength of the trunk and inferior members of patients with chronic lumbar pain. Joint, bone, spine : revue du rhumatisme. 2011; 78(3):291-7.

23. Granito R. Efeitos do envelhecimento e da osteoporose na cifose torácica, na propriocepção e no torque dos músculos do tronco. São Carlos, SP: Universidade Federal de São Carlos; 2005.

24. Lopez-Minarro PA, Muyor JM, Belmonte F, Alacid F. Acute effects of hamstring stretching on sagittal spinal curvatures and pelvic tilt. Journal of human kinetics. 2012; 31:69-78.

25. Cunha AC, Burke TN, Franca FJ, Marques AP. Effect of global posture reeducation and of static stretching on pain, range of motion, and quality of life in women with chronic neck pain: a randomized clinical trial. Clinics (Sao Paulo). 2008; 63(6):763-70.

26. Camargo LC. Efeitos imediatos do alongamento global na retração da cadeia muscular porterior-resposta eletromiografica, dinamometria e avaliação postural 2007.

27. Benedetti MG, Berti L, Presti C, Frizziero A, Giannini S. Effects of an adapted physical activity program in a group of elderly subjects with flexed posture: clinical and instrumental assessment. Journal of neuroengineering and rehabilitation. 2008; 5:32.

28. Porto F, Espinosa G, Vivian RC, Itaborahy AdS, Montenegro RA, Farinatti PdTV, et al. O exercício físico influencia a postura corporal de idosas? Motriz. 2012; 18(3):487-94.

29. Cardoso Junior MM. Avaliação ergonômica: Revisão dos métodos para avaliação postural. Revista Produção Online. 2006; 6(3).

30. Thomas JR, Nelson JK, Silverman SJ. Métodos de Pesquisa em Atividade Física. Porto Alegre: Artmed; 2012.

31. Prospero. Centre for Reviews and Dissemination: International propective register of systematic reviews 2014 02.Mar.2013. Available from: http://www.crd.york.ac.uk/PROSPERO/.

32. Moher D, Liberati A, Tetzlaff J, Altman DG. Preferred reporting items for systematic reviews and meta-analyses: the PRISMA statement. Annals of internal medicine. 2009; 151(4):264-9.

33. Pereira TA, Montero EFdS. DeCS terminology and the new rules on orthography of Portuguese language: guidelines for an update. Acta Cirurgica Brasileira. 2012; 27(7):509-14.

34. Lakatos E, Marconi M. Fundamentos de pesquisa metodológica científica. Revisada e ampliada. São Paulo: Atlas; 2003.

35. Kleiman A. Leitura: ensino e pesquisa1989.

36. Maher CG, Sherrington C, Herbert RD, Moseley AM, Elkins M. Reliability of the PEDro scale for rating quality of randomized controlled trials. Physical therapy. 2003; 83(8):713-21.

37. Verhagen AP, de Vet HC, de Bie RA, Kessels AG, Boers M, Bouter LM, et al. The Delphi list: a criteria list for quality assessment of randomized clinical trials for conducting systematic reviews developed by Delphi consensus. Journal of clinical epidemiology. 1998; 51(12):1235-41.

38. Sampaio RF, Mancini MC. Estudos de revisão sistemática: um guia para síntese criteriosa da evidência científica. Braz J Phys Ther(Impr). 2007; 11(1):83-9.

39. Arantes PM, Alencar MA, Dias RC, Dias JMD, Pereira LS. Atuação da fisioterapia na síndrome de fragilidade: revisão sistemática. Rev Bras Fisioter. 2009; 13(5):365-75.

40. Coury H, Moreira RF, Dias NB. Efetividade do exercício físico em ambiente ocupacional para controle da dor cervical, lombar e do ombro: uma revisão sistemática. Rev Bras Fisioter. 2009; 13(6):461-79. 
41. Sherrington C, Moseley A, Herbert R, Maher CG. Evidence for physiotherapy practice: a survey of the Physiotherapy Evidence Database (PEDro). Australian Journal of Physiotherapy. 2002; 48(1):43.

42. Marques AP, Mendonça Ld, Cossermelli W. Alongamento muscular em pacientes com fibromialgia a partir de um trabalho de reeducação postural global (RPG). Revista brasileira de reumatologia. 1994; 34(5):232-4.

43. HASHIMOTO B, TAKAHAGI LS, PACHIONI CAS. Análise da postura de participantes de um programa postural em grupo. Revista Eletrônica de Fisioterapia [Internet]. 2009 20.10.2013; 1(1):[46-62 pp.]. Available from: http:// docs.fct.unesp.br/cursos/fisioterapia/Revista\%20Eletronica\%20de\%20Fisioterapia/Artigos/03A.pdf.

44. Li Y, McClure PW, Pratt N. The effect of hamstring muscle stretching on standing posture and on lumbar and hip motions during forward bending. Phys Ther. 1996; 76(8):836-45; discussion 45-9.

45. DO ROSÁRIO JLP. Reeducação Postural Global e alongamento segmentar: um estudo comparativo: Universidade de São Paulo; 2003.

46. Muyor JM, López-Miñarro PA, Casimiro AJ. Effect of stretching program in an industrial workplace on hamstring flexibility and sagittal spinal posture of adult women workers: A randomized controlled trial. Journal of Back and Musculoskeletal Rehabilitation. 2012; 25(3):161-9.

47. Sacco IC, Melo MC, Rojas GB, Naki IK, Burgi K, Silveira LT, et al. Análise biomecânica e cinesiológica de posturas mediante fotografia digital: estudo de casos; Biomechanical and kinesiological study of postures trough digital photographs: cases report. Rev bras ciênc mov. 2003; 11(2):25-33.

48. Valduga R, Valduga LVA, Almeida JAd, Carvalho GA. Relação entre o padrão postural eo nível de atividade física em idosas. Revista Brasileira de Ciência e Movimento. 2013; 21(3):5-12.

49. Sinzato CR, Taciro C, Pio CdA, Toledo AMd, Cardoso JR, Carregaro RL. Effects of 20 sessions of Pilates method on postural alignment and flexibility of young women: pilot study. Fisioterapia e Pesquisa. 2013; 20(2):143-50.

50. Macedo RMB, Ulbricht L, da Vinha Ricieri D, Preis C, Duarte JM, Neto LB. Análise cinemática 2D da postura ortostática de ciclistas lombálgicos. Revista UNIANDRADE. 2013; 14(1):07-23.

51. Cunha EFD, Patrício NA, Macedo MC, Sena C, Kruschewsky R, Castro BG, et al. Postural profile of patients with HAM/ TSP: computerized and baropodometric assessment. Brazilian Journal of Medicine and Human Health. 2013; 1(1).

52. Silva Filho JN. Methods of evaluating postural deviations of the spine used in national studies: a systematic review. Manual Therapy, Posturology Rehabilitation Journal. 2014; 12:43-8.

53. Iunes D, Castro F, Salgado H, Moura I, Oliveira A, Bevilaqua-Grossi D. Confiabilidade intra e interexaminadores e repetibilidade da avaliação postural pela fotogrametria. Rev Bras Fisioter. 2005; 9(3):327-34.

54. Fortin C, Ehrmann Feldman D, Cheriet F, Labelle H. Clinical methods for quantifying body segment posture: a literature review. Disability and Rehabilitation. 2011; 33(5):367-83.

55. Iunes D, Bevilaqua-Grossi D, Oliveira A. Análise comparativa entre avaliação postural visual e por fotogrametria computadorizada. Rev bras fisioter. 2009; 13(4):308-15.

56. Döhnert M, Tomasi E. Validade da fotogrametria computadorizada na detecção de escoliose idiopática adolescente. Rev Bras Fisioter. 2008; 12(4):290-7.

57. Sacco I, Alibert S, Queiroz B, Pripas D, Kieling I, Kimura A, et al. Confiabilidade da fotogrametria em relação a goniometria para avaliação postural de membros inferiores. Rev Bras Fisioter. 2007; 11(5):411-7.

58. Jadad AR, Moore RA, Carroll D, Jenkinson C, Reynolds DJM, Gavaghan DJ, et al. Assessing the quality of reports of randomized clinical trials: is blinding necessary? Controlled clinical trials. $1996 ; 17(1): 1-12$.

59. Armstrong L. ACSM's guidelines for exercise testing and prescription/American College of: Lippincott Williams \& Wilkins, Philadelphia; 2006.

60. Rubini EC. Treinamento de Flexibilidade: da teoria a prática. Rio de Janeiro: Sprint; 2010. 112 p.

61. Balady GJ, Berra K, Golding L, Gordon N, Mahler D, Myers J, et al. Diretrizes do ACSM para os Testes de Esforço e sua Prescrição. Rio de Janeiro: Guanabara. 2003;239.

62. Verhagen AP, de Vet HC, de Bie RA, Boers M, A van den Brandt P. The art of quality assessment of RCTs included in systematic reviews. Journal of clinical epidemiology. 2001; 54(7):651-4.

63. Pereira BC, Medalha CC. Avaliação postural por fotometria em pacientes hemiplégicos. Conscientiae saúde. 2008; $7(1): 35-42$.

64. Malfair D, Flemming AK, Dvorak MF, Munk PL, Vertinsky AT, Heran MK, et al. Radiographic evaluation of scoliosis: review. American Journal of Roentgenology. 2010; 194(3_supplement):S8-S22.

65. Guermazi M, Ghroubi S, Kassis M, Jaziri O, Keskes H, Kessomtini W, et al. Validité et reproductibilité du Spinal

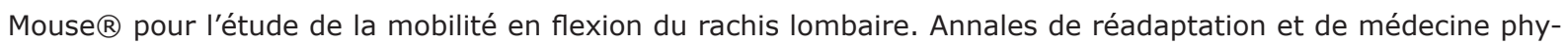
sique. $2006 ; 49(4): 172-7$. 